\title{
X-ray Fluorescence Techniques for Element Abundance Analysis in Wine
}

Jasmina Obhodaš,* Vladivoj Valković, Andrija Vinković, Davorin Sudac, Ivana Čanadija, Tihana Pensa, Zeljka Fiket, Anna Turyanskaya, Thomas Bretschneider, Christoph Wilhelmer, Gerelmaa Gunchin, Peter Kregsamer, Peter Wobrauschek, and Christina Streli

Cite This: ACS Omega 2021, 6, 22643-22654

Read Online

ACCESS | Lill Metrics \& More | 目 Article Recommendations | st Supporting Information

ABSTRACT: The elemental composition has been extensively used to characterize wine and to find correlations with environmental and winemaking factors. Although X-ray fluorescence (XRF) techniques offer many advantages, they have been rarely used for wine analysis. Here, we show the comparison of wine elemental composition results obtained by total reflection X-ray fluorescence (TXRF) and energy dispersive X-ray fluorescence (EDXRF) for elements $\mathrm{K}, \mathrm{Ca}, \mathrm{Mn}, \mathrm{Fe}, \mathrm{Cu}, \mathrm{Zn}, \mathrm{Br}, \mathrm{Rb}$, and $\mathrm{Sr}$. The results obtained by TXRF and EDXRF have been additionally verified by inductively coupled plasma-mass spectrometry. The important analytical features of XRF techniques in wine science have been described, the preservation of volatile elements (e.g., $\mathrm{Br}$ )

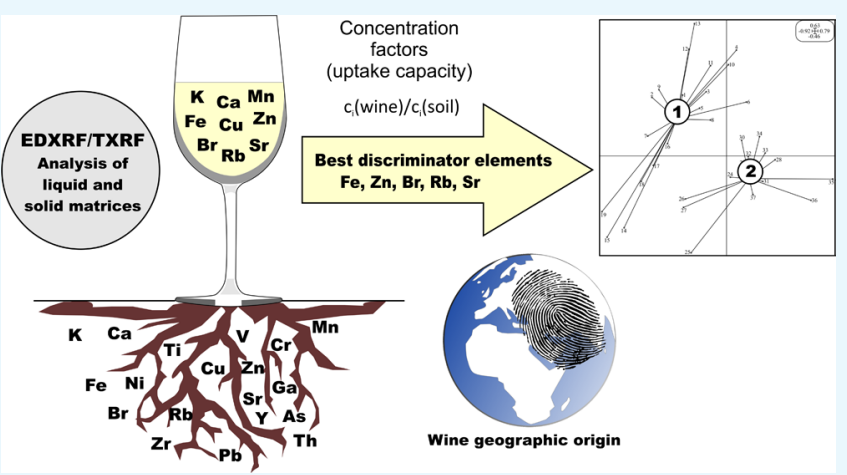
being one of their main advantages. In addition, we have shown that XRF techniques offer an optimal analytical approach for building large data sets containing highly reliable and reproducible results of elemental abundances in wines, corresponding soils, and grape juice. Such data sets are especially important for the geographic authentication of wine. This has been shown for 37 Austrian and Croatian wines collected together with respective soils from selected wine regions. The element abundances in soil reflect in a large portion in grape juice and finished wine suggesting that the contribution of the soil, that is, the plant uptake capacity expressed as $c_{\mathrm{i}}$ (wine) $/ c_{\mathrm{i}}$ (soil) concentration factors, can be a highly discriminating factor for wine fingerprinting. This indeed has been proved in the present study in comparison to discrimination based only on wine element abundances. We have identified $\mathrm{Fe}, \mathrm{Zn}, \mathrm{Br}, \mathrm{Rb}$, and $\mathrm{Sr}$ as the best discriminator elements for the geographical authentication of wine. The study opens a new perspective in extending the application of XRF techniques as a costeffective analytical tool for creating large databases of soil, grape juice, and wine element abundances for the evaluation of soil characteristics and other environmental parameters on wine composition.

\section{INTRODUCTION}

Studies of wine elemental composition improve our understanding of effects invoked by the environment and winemaking processes resulting in unique wine characteristics. The elemental composition of wine has been widely analyzed using different methods. A typical analytical approach for analyzing concentrations of different elements in wine is by using flame atomic emission (FAES) and flame absorption spectrometry (FAAS), ${ }^{1,2}$ inductively coupled plasma-mass spectrometry (ICP-MS $),^{3-5}$ and inductively coupled plasma-optical emission spectrometry or atomic emission spectrometry (ICP-OES/ICP-AES). ${ }^{6,7}$ The abovementioned techniques are all destructive, which could lead to the possible loss of volatile elements, for example, Br. Compared to FAES and FAAS, ICP-MS and ICP-OES/ICP-AES are multi-elemental but more expensive and involve high maintenance costs. On the other hand, total reflection X-ray fluorescence (TXRF) and energy dispersive $\mathrm{X}$-ray fluorescence (EDXRF) techniques are multi-elemental, affordable, non-destructive, and require minimal sample preparation. TXRF enables the direct application of the small amount of the sample (typically 5$10 \mu \mathrm{L}$ ) on the sample holder, followed by a short drying at low temperatures (below $50{ }^{\circ} \mathrm{C}$ ). EDXRF requires a larger amount of the sample (typically $1-2 \mathrm{~g}$ ) and the sample preconcentration by lyophilization (freeze-drying). Samples prepared for TXRF and EDXRF retain most of the volatile elements. Both techniques are easy to use and have a high throughput. EDXRF is especially useful if the wine concentration needs to be related to the corresponding soil

Received: May 25, 2021

Accepted: July 30, 2021

Published: August 24, 2021

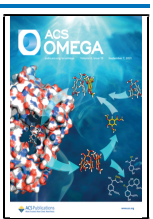




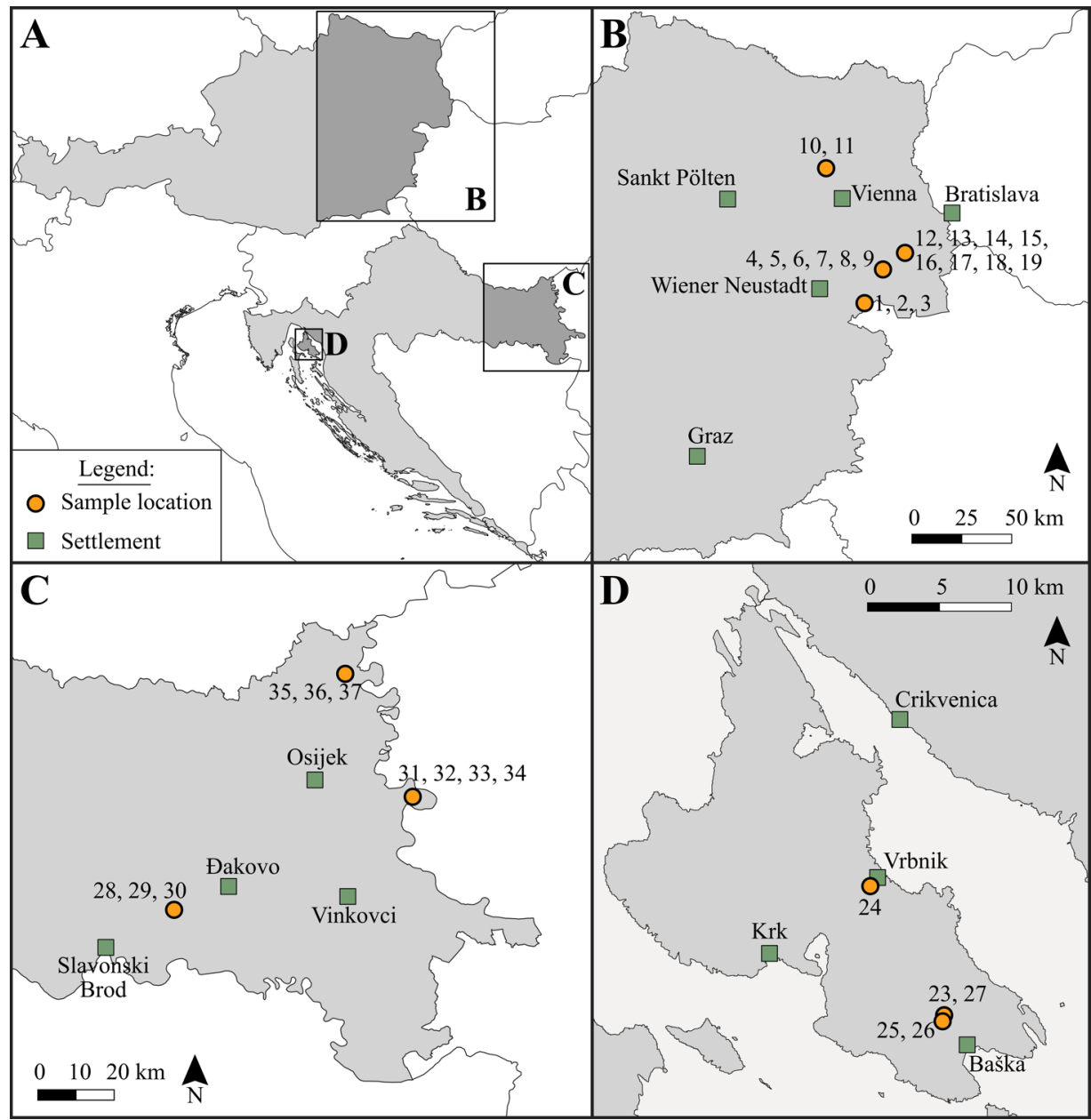

Figure 1. Sampling locations in (A) Austria and Croatia; (B) Eastern Austria; (C) Eastern Croatia; and (D) Island of Krk-northern Croatian Littoral.

because EDXRF is also suitable for the analysis of mineral samples; thus, both matrices, wine, and soil can be analyzed by the same technique. TXRF compared to EDXRF is more appropriate for liquid samples and has a lower detection limit, down to parts-per-trillion $\left(10^{-12}\right)$, whereas the EDXRF detection limit is usually in parts-per-million $\left(10^{-6}\right)$. TXRF has already been proved useful in wine analysis, ${ }^{8-10}$ while EDXRF optimized for the wine analysis using lyophilization was recently developed in the Ruder Boškovic laboratory, and some preliminary results have been published by Sudac et al. ${ }^{11}$ There were attempts to use EDXRF on samples preconcentrated by co-precipitation with the ammonium pyrrolidine dithiocarbamate complex; ${ }^{12,13}$ however, obtained results underestimated concentrations of some measured elements (e.g., $\mathrm{Fe}$ and $\mathrm{Zn}$ ) that would be expected in wine. The disadvantage of using lyophilization as a pre-concentration technique is the initial costs of laboratory equipment (between $€ 10,000$ and $€ 25,000$ as of 2021) and the required time to complete the process which typically takes 2 days. However, both EDXRF and TXRF can be combined in one instrument by attaching TXRF and EDXRF modules to the same excitation source, which makes instrumentation even more versatile and cost-effective.

Recently, the elemental composition has been extensively applied to geographical authentication ${ }^{14-21}$ (more references are given in Supporting Information, Table S4). Each segment of the environment in which certain wine is produced, including factors such as soil, topography, climate, soil fauna, viticulture, and wine production tradition, is reflected in a wine elemental composition. This is the basis for distinguishing the geographic provenience of wine (wine authentication). Although many studies have shown that elemental analysis of wine can be used for discriminating wines by regions, only a few studies related elemental composition of wine to the respective soil. ${ }^{1,22-27}$ In this study, we will show that the $c_{\mathrm{i}}$ (wine) $/ c_{\mathrm{i}}$ (soil) ratio (concentration factor) of selected elements provides valuable information on wine geographic origin. Geographic authentication of wine is especially useful if databases contain results of many different samples of wine and soil characteristics collected across different regions. ${ }^{27}$ This positions cost-effective XRF techniques as very appropriate for building large databases containing results of wine and corresponding soil analysis.

Here, we present the comparison of results obtained using TXRF and EDXRF, which have been additionally verified by ICP-MS. Wines were collected by wine producers in selected Austrian and Croatian regions along with soils from the respective vineyards. The sampling locations are presented in Figure 1. The geographic authentication was evaluated by discriminant analyses. The best results were obtained when the $c_{\mathrm{i}}($ wine $) / c_{\mathrm{i}}($ soil $)$ concentration factor was considered. 
Table 1. Results of Descriptive Statistics for Wine and Soil Samples Measured with EDXRF, TXRF, and ICP-MS ${ }^{a}$

\begin{tabular}{|c|c|c|c|c|c|c|c|c|c|c|}
\hline element & $N$ & mean & median & $\min$ & $\max$ & lower quartile & upper quartile & St. Dev. & Sk. & Kurt. \\
\hline \multicolumn{11}{|c|}{ EDXRF-wine } \\
\hline $\mathrm{K}$ & 37 & 927.9 & 808.7 & 394.5 & 2195.4 & 711.00 & 1162.0 & 370.4 & 1.35 & 2.71 \\
\hline $\mathrm{Ca}$ & 37 & 64.2 & 66.4 & 1.4 & 108.3 & 47.2 & 75.8 & 22.8 & -0.29 & 0.46 \\
\hline $\mathrm{Mn}$ & 37 & 0.990 & 1.024 & 0.339 & 1.747 & 0.822 & 1.125 & 0.257 & 0.23 & 1.70 \\
\hline $\mathrm{Fe}$ & 37 & 1.452 & 1.325 & 0.405 & 4.284 & 0.942 & 1.845 & 0.825 & 1.78 & 4.29 \\
\hline $\mathrm{Cu}$ & 37 & 0.084 & 0.075 & 0.046 & 0.267 & 0.067 & 0.090 & 0.037 & 3.53 & 16.23 \\
\hline $\mathrm{Zn}$ & 37 & 0.629 & 0.585 & 0.252 & 1.817 & 0.447 & 0.712 & 0.297 & 1.95 & 5.94 \\
\hline $\mathrm{Br}$ & 36 & 0.074 & 0.035 & 0.009 & 0.293 & 0.024 & 0.116 & 0.068 & 1.34 & 1.64 \\
\hline $\mathrm{Rb}$ & 37 & 0.964 & 0.809 & 0.293 & 3.463 & 0.550 & 1.009 & 0.654 & 2.46 & 6.84 \\
\hline $\mathrm{Sr}$ & 37 & 0.317 & 0.326 & 0.061 & 0.628 & 0.215 & 0.385 & 0.123 & 0.17 & 0.07 \\
\hline \multicolumn{11}{|c|}{ TXRF-wine } \\
\hline $\mathrm{K}$ & 37 & 878.5 & 875.5 & 333.1 & 1470.7 & 717.4 & 1171.3 & 307.4 & -0.12 & -0.90 \\
\hline $\mathrm{Ca}$ & 37 & 67.9 & 65.9 & 35.7 & 128.6 & 47.6 & 83.1 & 23.0 & 0.60 & -0.09 \\
\hline $\mathrm{Mn}$ & 37 & 0.955 & 0.812 & 0.332 & 2.019 & 0.655 & 1.208 & 0.433 & 1.02 & 0.45 \\
\hline $\mathrm{Fe}$ & 35 & 1.346 & 1.036 & 0.338 & 6.053 & 0.590 & 1.509 & 1.168 & 2.74 & 8.73 \\
\hline $\mathrm{Cu}$ & 28 & 0.150 & 0.076 & 0.028 & 1.229 & 0.038 & 0.120 & 0.245 & 3.62 & 14.57 \\
\hline $\mathrm{Zn}$ & 37 & 0.664 & 0.576 & 0.124 & 2.038 & 0.359 & 0.806 & 0.415 & 1.33 & 2.02 \\
\hline $\mathrm{Br}$ & 36 & 0.077 & 0.051 & 0.021 & 0.197 & 0.038 & 0.113 & 0.050 & 0.84 & -0.43 \\
\hline $\mathrm{Rb}$ & 37 & 1.113 & 0.932 & 0.355 & 3.734 & 0.740 & 1.219 & 0.685 & 2.53 & 7.60 \\
\hline $\mathrm{Sr}$ & 37 & 0.319 & 0.326 & 0.034 & 0.681 & 0.216 & 0.398 & 0.132 & 0.24 & 0.59 \\
\hline \multicolumn{11}{|c|}{ ICP-MS-wine } \\
\hline $\mathrm{K}$ & 8 & 1074.3 & 1107.8 & 139.3 & 1495.3 & 951.9 & 1420.2 & 435.6 & -1.53 & 2.96 \\
\hline $\mathrm{Mn}$ & 8 & 1.1 & 1.0 & 0.5 & 1.7 & 0.8 & 1.5 & 0.5 & 0.33 & -0.92 \\
\hline $\mathrm{Fe}$ & 8 & 1.050 & 0.968 & 0.080 & 2.693 & 0.626 & 1.221 & 0.766 & 1.41 & 3.32 \\
\hline $\mathrm{Cu}$ & 8 & 0.231 & 0.115 & 0.048 & 0.748 & 0.061 & 0.350 & 0.260 & 1.53 & 1.22 \\
\hline $\mathrm{Rb}$ & 8 & 1.381 & 1.404 & 0.744 & 2.091 & 1.030 & 1.672 & 0.461 & -0.17 & -0.42 \\
\hline $\mathrm{Sr}$ & 8 & 0.453 & 0.444 & 0.223 & 0.771 & 0.338 & 0.535 & 0.169 & 0.68 & 0.90 \\
\hline \multicolumn{11}{|c|}{ EDXRF-grape juice } \\
\hline $\mathrm{K}$ & 7 & 1100.8 & 962.9 & 413.1 & 1622.8 & 720.4 & 1592.8 & 461.7 & -0.21 & -1.39 \\
\hline $\mathrm{Ca}$ & 6 & 71.8 & 89.0 & 24.0 & 100.2 & 30.7 & 92.8 & 32.9 & -0.88 & -1.87 \\
\hline $\mathrm{Mn}$ & 7 & 0.704 & 0.828 & 0.173 & 1.057 & 0.467 & 1.057 & 0.334 & -0.49 & -1.04 \\
\hline $\mathrm{Fe}$ & 7 & 2.579 & 2.574 & 1.864 & 3.221 & 2.061 & 2.991 & 0.483 & -0.34 & -0.81 \\
\hline $\mathrm{Cu}$ & 7 & 0.481 & 0.512 & 0.333 & 0.582 & 0.428 & 0.548 & 0.087 & -0.69 & -0.43 \\
\hline $\mathrm{Zn}$ & 7 & 2.036 & 2.126 & 1.401 & 2.867 & 1.705 & 2.322 & 0.485 & 0.55 & 0.25 \\
\hline $\mathrm{Br}$ & 2 & 0.106 & 0.106 & 0.078 & 0.133 & 0.078 & 0.133 & 0.039 & & \\
\hline $\mathrm{Rb}$ & 7 & 1.008 & 0.727 & 0.514 & 1.715 & 0.664 & 1.437 & 0.461 & 0.59 & -1.52 \\
\hline $\mathrm{Sr}$ & 7 & 0.102 & 0.098 & 0.023 & 0.206 & 0.087 & 0.115 & 0.054 & 0.90 & 2.92 \\
\hline \multicolumn{11}{|c|}{ EDXRF-soil } \\
\hline $\mathrm{K}$ & 33 & 18567 & 17050 & 12100 & 27750 & 15300 & 20050 & 4631 & 0.95 & -0.31 \\
\hline $\mathrm{Ca}$ & 33 & 50356 & 20100 & 4550 & 194600 & 8450 & 71600 & 54461 & 1.36 & 1.20 \\
\hline $\mathrm{Ti}$ & 33 & 5732 & 5334 & 2555 & 10156 & 4601 & 6832 & 1841 & 0.43 & 0.07 \\
\hline $\mathrm{V}$ & 33 & 130.3 & 137.8 & 55.8 & 191.0 & 99.3 & 161.6 & 35.5 & -0.33 & -0.72 \\
\hline $\mathrm{Cr}$ & 33 & 102.7 & 92.1 & 37.3 & 199.1 & 72.5 & 124.1 & 42.3 & 0.73 & -0.29 \\
\hline $\mathrm{Mn}$ & 33 & 832.7 & 815.1 & 510.0 & 1390.0 & 690.6 & 918.9 & 223.6 & 1.01 & 0.99 \\
\hline $\mathrm{Fe}$ & 33 & 43727.6 & 42840.0 & 21400.0 & 63735.0 & 34980.0 & 53570.0 & 12574.1 & 0.04 & -0.92 \\
\hline $\mathrm{Ni}$ & 33 & 47.1 & 44.3 & 24.1 & 130.0 & 36.4 & 53.8 & 18.8 & 2.85 & 11.48 \\
\hline $\mathrm{Cu}$ & 33 & 47.2 & 45.6 & 16.5 & 92.8 & 35.3 & 55.3 & 20.6 & 0.67 & -0.19 \\
\hline $\mathrm{Zn}$ & 33 & 125.9 & 120.8 & 85.7 & 167.1 & 114.0 & 140.4 & 20.3 & 0.29 & -0.36 \\
\hline $\mathrm{Ga}$ & 33 & 19.3 & 19.7 & 8.3 & 36.8 & 14.7 & 23.7 & 6.9 & 0.29 & -0.19 \\
\hline As & 33 & 12.9 & 9.1 & 5.4 & 38.7 & 7.9 & 12.8 & 8.9 & 1.84 & 2.68 \\
\hline $\mathrm{Br}$ & 33 & 8.0 & 5.4 & 2.5 & 41.3 & 4.3 & 6.8 & 8.4 & 2.97 & 8.76 \\
\hline $\mathrm{Rb}$ & 33 & 132.2 & 135.9 & 73.9 & 194.0 & 97.0 & 154.1 & 34.2 & -0.04 & -1.11 \\
\hline $\mathrm{Sr}$ & 33 & 160.6 & 155.2 & 87.4 & 310.9 & 129.9 & 183.0 & 47.7 & 1.76 & 4.67 \\
\hline $\mathrm{Y}$ & 33 & 42.8 & 41.9 & 23.5 & 65.7 & 34.0 & 52.1 & 11.4 & 0.04 & -0.81 \\
\hline $\mathrm{Zr}$ & 33 & 435.7 & 421.0 & 109.6 & 907.6 & 239.3 & 552.0 & 231.4 & 0.28 & -0.88 \\
\hline $\mathrm{Pb}$ & 33 & 29.5 & 27.2 & 15.5 & 51.0 & 21.8 & 34.9 & 9.6 & 0.74 & -0.11 \\
\hline $\mathrm{Th}$ & 33 & 16.1 & 15.6 & 5.5 & 29.7 & 11.0 & 20.0 & 6.3 & 0.34 & -0.37 \\
\hline
\end{tabular}

${ }^{a_{T}}$ The concentrations in wine and soil are expressed as $\mathrm{mg} / \mathrm{L}$ and $\mathrm{mg} / \mathrm{kg}$, respectively. 

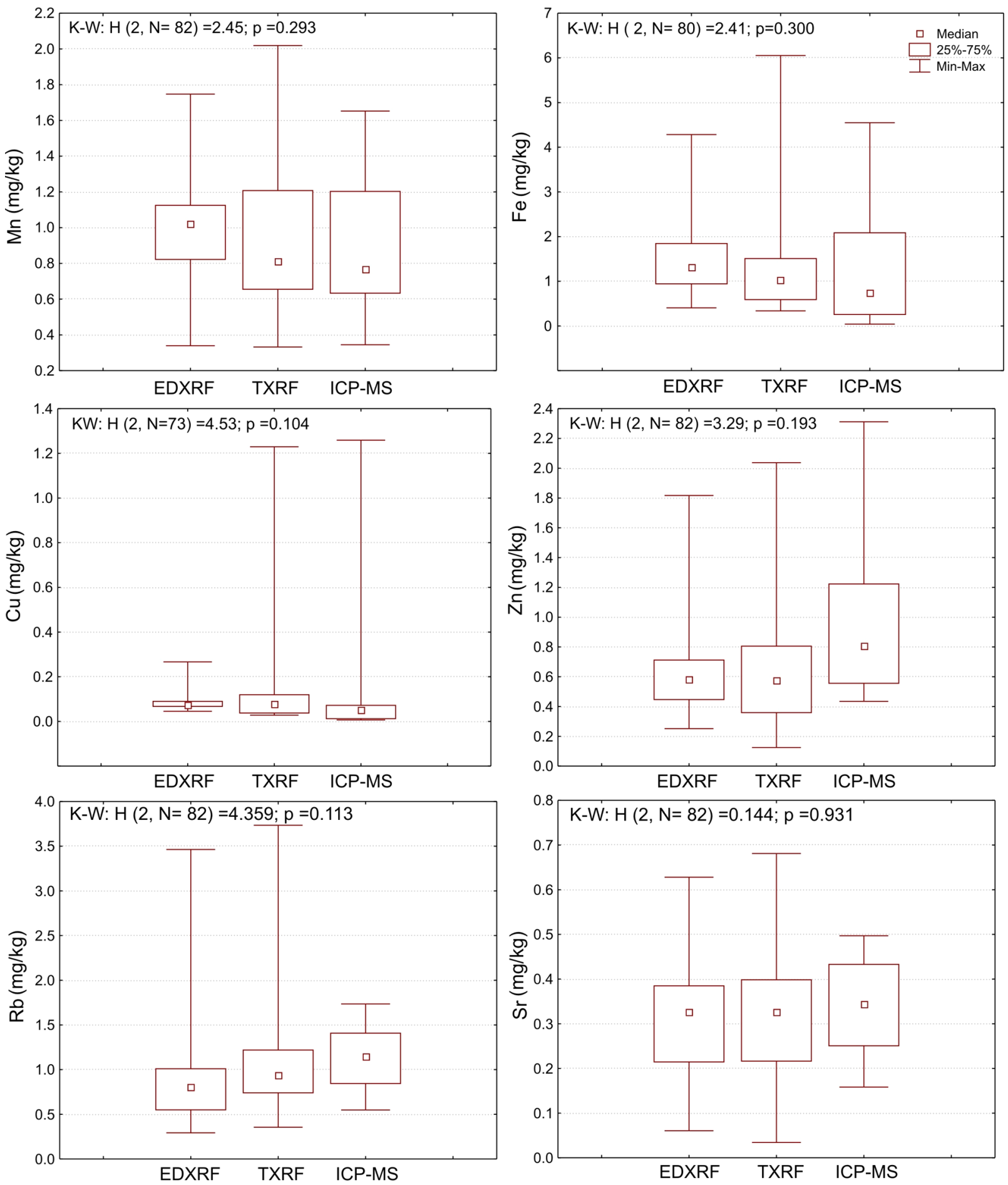

Figure 2. Box-plot diagrams and $\mathrm{KW}$ tests for concentrations of $\mathrm{Mn}, \mathrm{Fe}, \mathrm{Cu}, \mathrm{Zn}, \mathrm{Rb}$, and $\mathrm{Sr}$ obtained using EDXRF, TXRF, and ICP-MS in wine.

\section{RESULTS AND DISCUSSION}

2.1. Wine, Grape Juice, and Soil Analyses. The results of descriptive statistics for wines analyzed by EDXRF, TXRF, and ICP-MS and grape juice and soils analyzed by EDXRF are presented in Table 1 . The results of the analyses are given in Supporting Information, Table S3. According to the regulation for maximum acceptable limits (MAL) of contaminants in wine defined by the International Organisation of Vine and Wine, ${ }^{28}$ concentrations of $\mathrm{Zn}$ and $\mathrm{Br}$ were all well below MAL, while one value of the $\mathrm{Cu}$ concentration measured by TXRF (wine no. 11) and ICP-MS (wine no. 29) exceeded the MAL of $1 \mathrm{mg} / \mathrm{L}$. Since the exceeded values were not confirmed by the either of other two methods, it is possible that $\mathrm{Cu}$ is not uniformly distributed in measured samples, or these "outliers" were caused by after-sampling contamination of an unknown source.

Comparison of $\mathrm{Mn}, \mathrm{Fe}, \mathrm{Cu}, \mathrm{Zn}, \mathrm{Rb}$, and $\mathrm{Sr}$ concentrations obtained using EDXRF, TXRF, and ICP-MS is shown in boxplot diagrams presented in Figure 2 together with results of Kruskal-Wallis (KW) tests. KW analysis has shown that concentrations of these elements obtained using different 

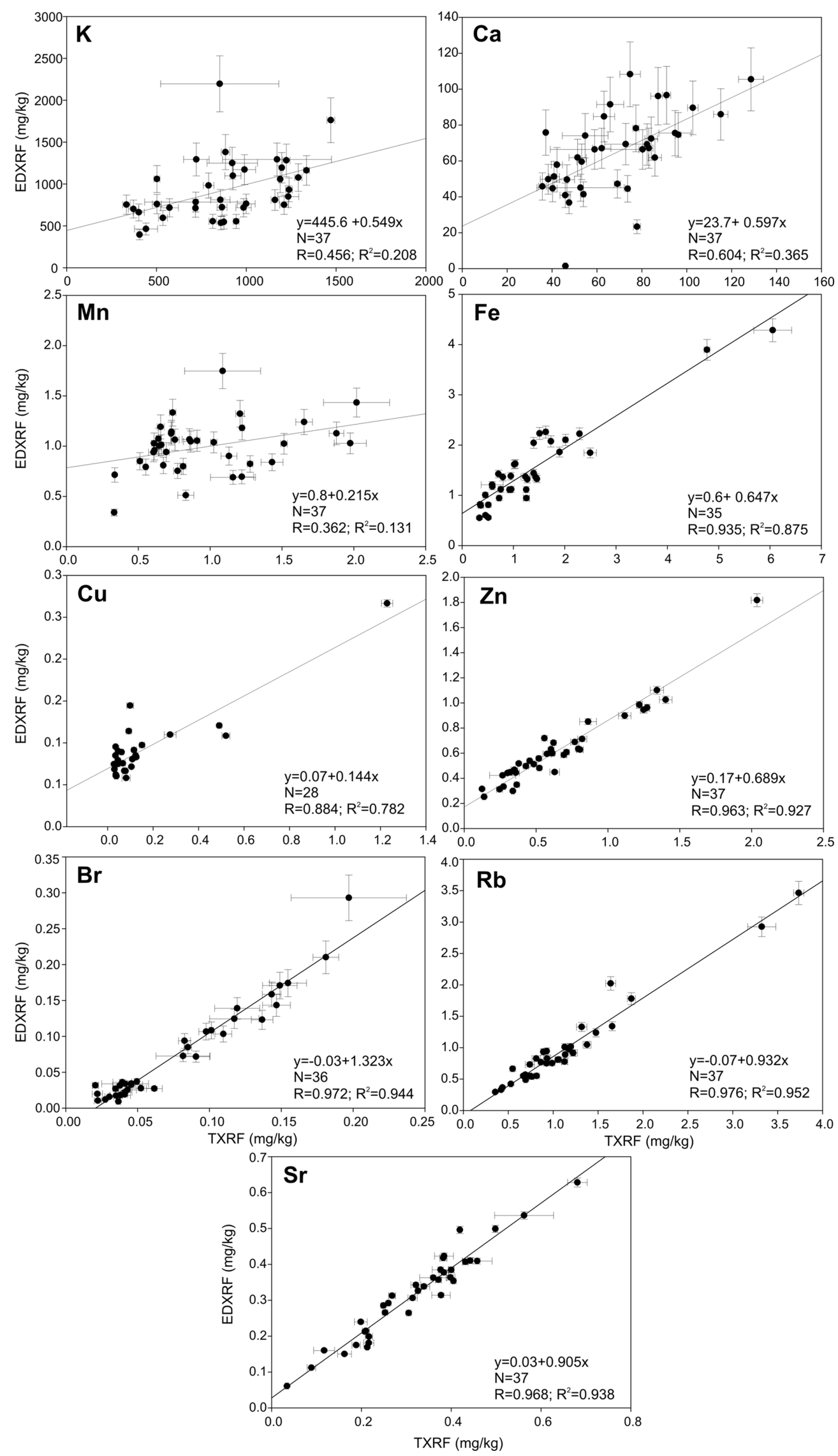

Figure 3. Regression linear analysis for $\mathrm{K}, \mathrm{Ca}, \mathrm{Mn}, \mathrm{Fe}, \mathrm{Cu}, \mathrm{Zn}, \mathrm{Br}, \mathrm{Rb}$, and $\mathrm{Sr}$ concentrations in wine obtained using EDXRF and TXRF. 


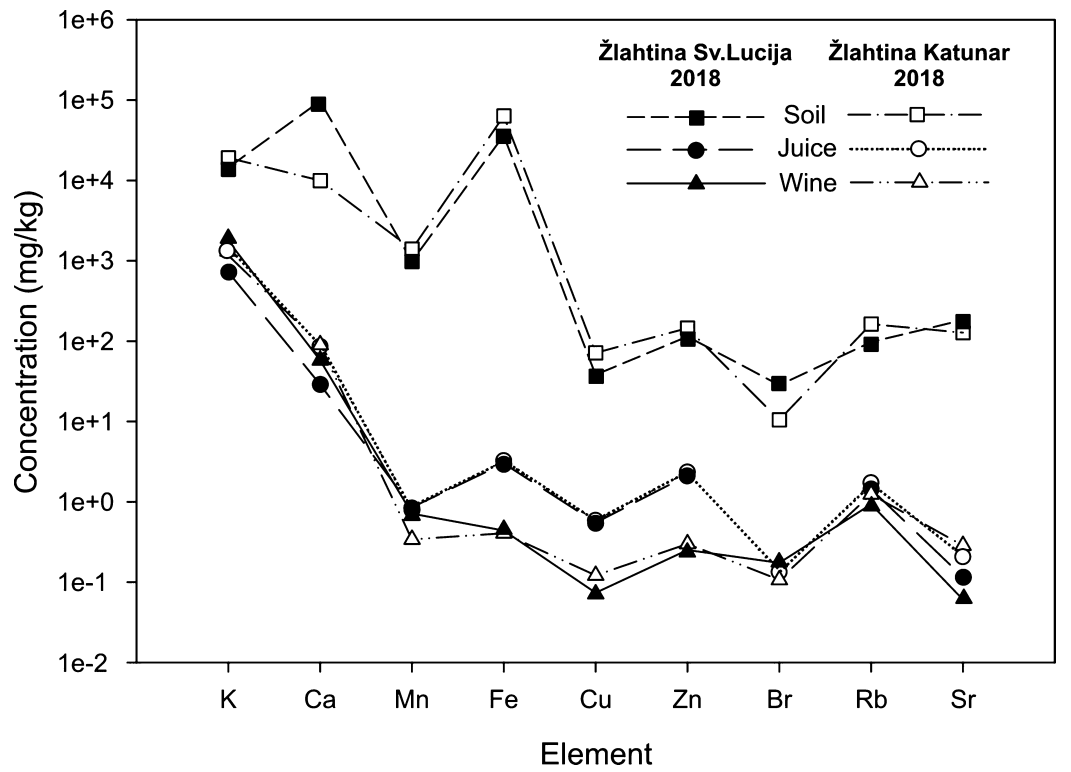

Figure 4. Comparison of two young wines of the same varieties (Žlahtina Sv. Lucija, 2018 and Žlahtina Katunar, 2018) with regard to K, Ca, Mn, $\mathrm{Fe}, \mathrm{Cu}, \mathrm{Zn}, \mathrm{Br}, \mathrm{Rb}$, and $\mathrm{Sr}$ concentrations analyzed in grape juice and respective wines and soils.

techniques belong to the same distribution; thus, the results are statistically comparable.

Linear regression analysis for concentrations of $\mathrm{K}, \mathrm{Ca}, \mathrm{Mn}$, $\mathrm{Fe}, \mathrm{Cu}, \mathrm{Zn}, \mathrm{Br}, \mathrm{Rb}$, and $\mathrm{Sr}$ measured by TXRF and EDXRF is presented in Figure 3. The results indicate the inhomogeneity of wine samples considering $\mathrm{K}, \mathrm{Ca}$, and $\mathrm{Mn}$ concentrations, which should be taken into account when performing assessments based on element abundances such as the geographical provenance of wine. The precaution should be taken considering wine fining agents that might be added into the must during the fermentation process and for improving the final wine. These fining agents might influence the natural elemental composition of wine, as described in the next chapter.

2.2. Wine Fining Agents Influencing the Wine Elemental Abundance. Different regions traditionally use different winemaking practices which are in European Commission authorized and restricted by the regulation EC2019/934. ${ }^{29}$ A number of compounds might be added under strictly controlled conditions as acidity regulators, preservatives, and clarifying and stabilizing agents and for correction of wine defects. We will describe authorized oenological compounds that might modify natural wine elemental abundances measured in the present study. One of the most common compounds in winemaking practices is potassium metabisulfite $\left(\mathrm{K}_{2} \mathrm{~S}_{2} \mathrm{O}_{5}\right)$ or potassium bisulfite $\left(\mathrm{KHSO}_{3}\right)$, which is added during wine fermentation as a source of sulfur dioxide $\left(\mathrm{SO}_{2}\right)$ for biocidal and oxidation prevention purposes. The upper $\mathrm{SO}_{2}$ limit of wines on their release to the market for direct human consumption is 150 $\mathrm{mg} / \mathrm{L}$ for red wines and $200 \mathrm{mg} / \mathrm{L}$ for white and rosé wines. ${ }^{29}$ The winemakers would commonly add no more than $100 \mathrm{mg} /$ $\mathrm{L}$ of $\mathrm{K}_{2} \mathrm{~S}_{2} \mathrm{O}_{5}$ during the must fermentation which would result in approximately $35 \mathrm{mg} / \mathrm{L}$ of added $\mathrm{K}$. The upper limit of $\mathrm{SO}_{2}$ concentrations would be achieved by adding approximately 260 and $350 \mathrm{mg} / \mathrm{L}$ of $\mathrm{K}_{2} \mathrm{~S}_{2} \mathrm{O}_{5}$ to red and white wines, respectively, resulting in $90 \mathrm{mg} / \mathrm{L}$ of additionally added $\mathrm{K}$ in red and $120 \mathrm{mg} / \mathrm{L}$ in white wines. The addition of $\mathrm{K}_{2} \mathrm{~S}_{2} \mathrm{O}_{5}$ would typically result in $3-10 \%$ of total $\mathrm{K}$ in wine.
The EC2019/934 also regulates the addition and removal of excess $\mathrm{Ca}, \mathrm{Fe}$, and $\mathrm{Cu}$ during the winemaking process. ${ }^{29}$ Winemakers might add potassium ferrocyanide $\left(\mathrm{K}_{4}[\mathrm{Fe}-\right.$ $\left.\left.(\mathrm{CN})_{6}\right]\right)$ or calcium phytate $\left(\mathrm{C}_{6} \mathrm{H}_{6} \mathrm{Ca}_{6} \mathrm{O}_{24} \mathrm{P}_{6}\right)$ to remove an excess of $\mathrm{Fe}$ (if $\mathrm{Fe}>5 \mathrm{mg} / \mathrm{L}$ ). The procedure involving $\mathrm{K}_{4}\left[\mathrm{Fe}(\mathrm{CN})_{6}\right]$ requires careful removal of all ferric ferrocyanide residues before wine bottling. ${ }^{30}$ However, with the introduction of the modern stainless steel equipment with which the wine comes in contact, there is a small probability that removal of $\mathrm{Fe}$ excess would be necessary. Copper sulfate $\left(\mathrm{CuSO}_{4}\right)$ or cupric citrate $\left(\mathrm{C}_{6} \mathrm{H}_{4} \mathrm{Cu}_{2} \mathrm{O}_{7}\right)$ might be added to wine to remove excess volatile sulfur-containing compounds (e.g., hydrogen sulfide, $\mathrm{H}_{2} \mathrm{~S}$ ) responsible for defects of wine taste or smell. When adding these compounds, care should be taken not to exceed $1 \mathrm{mg} / \mathrm{L}$ of $\mathrm{Cu}$ in the final product. ${ }^{29}$ Winemakers would usually add 0.1 to $0.2 \mathrm{~mL} / \mathrm{L}$ of $1 \% \mathrm{CuSO}_{4}$ during the fermentation, which would result in 0.398 to $0.796 \mathrm{mg} / \mathrm{L}$ of additionally added $\mathrm{Cu}$ in wine. The addition is unlikely to result in increased residual $\mathrm{Cu}$ in the final wine as long as the wine is removed from gross lees shortly after the treatment. ${ }^{31}$ If the content of $\mathrm{Cu}$ in wine is too high $(>1 \mathrm{mg} / \mathrm{L})$, the imidazole-based polymers might be added for the efficient reduction of excess $\mathrm{Cu}$ concentrations. ${ }^{32}$ These and other oenological practices, such as de-acidification of wine [e.g., using potassium or calcium carbonate $\left(\mathrm{K}_{2} \mathrm{CO}_{3}\right.$ or $\left.\mathrm{CaCO}_{3}\right)$, potassium bicarbonate $\left(\mathrm{KHCO}_{3}\right)$, or potassium tartrate $\left.\left(\mathrm{K}_{2} \mathrm{C}_{6} \mathrm{H}_{4} \mathrm{O}_{6}\right)\right]$, the addition of bentonite or kaolin for white wine clarification, and so forth, have to be taken into consideration when evaluating the wine geographic origin based on wine element abundances, as shown in the example below.

2.3. Discrimination of Wines Based on Element Abundances. Figure 4 shows the graphical comparison for two young wines of the same varieties (Žlahtina Katunar and Žlahtina Sv. Lucija) considering elements $\mathrm{K}, \mathrm{Ca}, \mathrm{Mn}, \mathrm{Fe}, \mathrm{Cu}$, $\mathrm{Zn}, \mathrm{Br}, \mathrm{Rb}$, and $\mathrm{Sr}$ analyzed in grape juice and corresponding wines and soils. The lower concentrations in wine compared to grape juice were observed with respect to $\mathrm{Fe}, \mathrm{Cu}$, and $\mathrm{Zn}$ which can be explained with metabolic processes of yeast and 

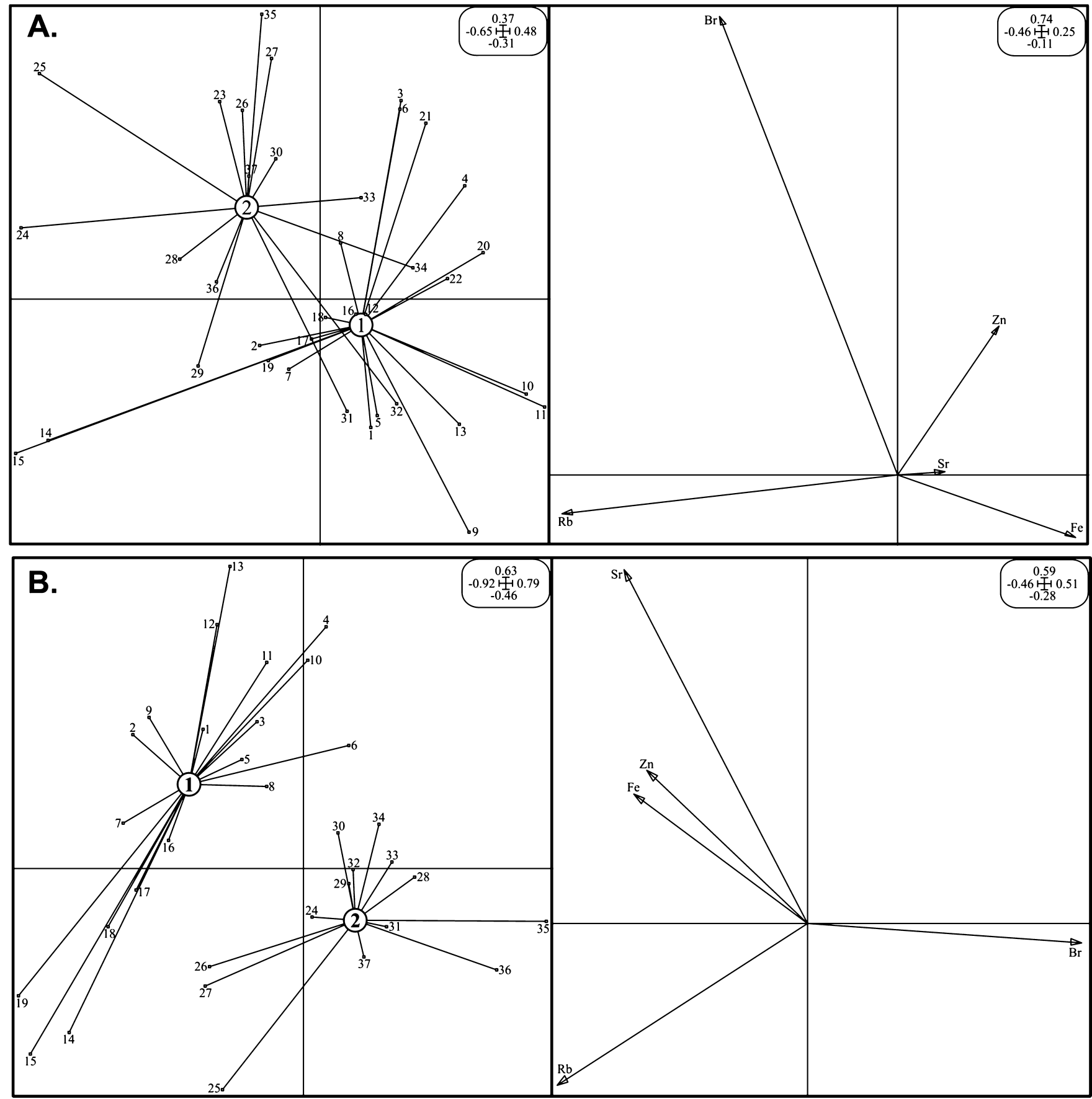

Figure 5. Presentation of samples associated with predetermined groups (1-Austria and 2-Croatia) by BG-PCA using (A) concentrations of Fe, Zn, $\mathrm{Br}, \mathrm{Rb}$, and $\mathrm{Sr}$ in wine and $(\mathrm{B})$ concentration factors $\left[c_{\mathrm{i}}(\right.$ wine $) / c_{\mathrm{i}}($ soil $\left.)\right]$ of the same elements.

precipitation of lees. Concentrations of other elements are slightly lower in wine compared to grape juice, except for $\mathrm{K}$ which was higher in both wines, and $\mathrm{Ca}$ and $\mathrm{Sr}$ which were higher in Katunar wine compared to the corresponding grape juice. Although Pearson's correlation test did not deliver any significant statistical correlation between 32 samples of wines and corresponding soils (with exception of $\mathrm{Ca}$ and $\mathrm{Br}$, in which correlations were driven by few outliers), the significant statistical correlations were found when elements in common were compared between grape juice, wines, and respective soils in two Zlahtina wines (Katunar and Sv. Lucija) using Spearman Rank Order analysis (Supporting Information, Table S6.1, S6.2). Grape juice and wines were correlated 82 and $87 \%$, while soils and wines were correlated 64 and $87 \%$ for Katunar and Sv. Lucija, respectively. The results show the high portion of soil and grape juice composition reflecting in wine elemental abundances. There is a clear difference in soil and wine concentrations measured for two wines of the same variety but associated with different vineyards and types of soils, which can be observed in Figure 4. This suggests that the contribution of the soil, that is, the plant uptake capacity expressed as the $c_{\mathrm{i}}$ (wine) $/ c_{\mathrm{i}}$ (soil) concentration factor, can be a highly discriminating factor for wine fingerprinting, even if the same grape varieties growing in the same clime (but in different soil types) are compared. 
The elements of interest for authentication of wine provenance should be carefully selected. Of all elements analyzed in the present study, $\mathrm{K}$ is the least appropriate for it is commonly added during wine production to protect wine from oxidation. The formation of $\mathrm{K}$ bitartrate and $\mathrm{Ca}$ tartrate crystals during wine stabilization and aging ${ }^{1}$ could explain the inhomogeneity of $\mathrm{K}$ and $\mathrm{Ca}$ concentrations in wines, as indicated by plots presented in Figure 3. The large inhomogeneity was observed also for Mn (Figure 3 ). If this would be confirmed by other studies, then $\mathrm{Ca}$ and $\mathrm{Mn}$, along with $\mathrm{K}$, should not be considered for the wine geographic authentication assessment due to their uneven distribution in the wine. The unusually high concentrations of $\mathrm{Cu}$ in wine might be indicative of its addition as a wine fining agent. Since this is not a rare oenological practice, we recommend avoiding $\mathrm{Cu}$ for the wine origin authentication.

The examination of 53 papers, in which authors have used the elemental composition of wines for successful determination of their geographical provenience (see Supporting Information, Table S4), revealed that the most frequently used elements for the best discrimination among different wine varieties were $\mathrm{Sr}(66.04 \%), \mathrm{Mn}$ (54.72\%), Rb (50.94\%), $\mathrm{Zn}$ (49.06\%), and $\mathrm{Fe}(28.30 \%)$. These elements are easily analyzed by the most conventional techniques, including $\mathrm{XRF}$, and have yielded good results in connecting wines to their environment of origin. Here, we show that $\mathrm{Br}$ is also a very good discriminating parameter for geographic authentication, especially if $c_{\mathrm{i}}$ (wine) $/ c_{\mathrm{i}}$ ( soil) concentration factors are considered. Figure 5 presents results of the between groupprincipal component analysis (BG-PCA) for $c_{i}$ (wine) and $c_{\mathrm{i}}$ (wine) $/ c_{\mathrm{i}}$ (soil) concentration factors on predetermined classes of wines according to the country of origin (Austria and Croatia), taking into account concentrations of $\mathrm{Fe}, \mathrm{Zn}, \mathrm{Br}$, $\mathrm{Rb}$, and $\mathrm{Sr}$. The combination of $c_{\mathrm{i}}$ (wine) $/ c_{\mathrm{i}}$ (soil) concentration factors for selected elements expresses the relation between the grapevine and soil chemical and physical characteristics reflected in the wine composition. By examining Figure 5, a similar arrangement of $\mathrm{Fe}, \mathrm{Zn}, \mathrm{Br}, \mathrm{Rb}$, and $\mathrm{Sr}$ as discriminating factors in $c_{\mathrm{i}}$ (wine) and $c_{\mathrm{i}}$ (wine) $/ c_{\mathrm{i}}$ (soil) analyses was noted; however, the separation of samples is better for $c_{\mathrm{i}}$ (wine)/ $c_{\mathrm{i}}\left(\right.$ soil). When using $c_{\mathrm{i}}$ (wine) $/ c_{\mathrm{i}}$ (soil) concentration factors none of the samples were wrongly classified, while data of concentrations in wines yielded $19 \%$ of samples that were not clearly separated considering the country of origin. Furthermore, the grouping by BG-PCA mixed the red and white wines samples showing that element abundances are not variety specific, thus confirming the results from the study of van der Linde et al. ${ }^{25}$

When examining two consecutive production years of the same wine, we have found $100 \%$ agreement in 5 out of 10 pairs with respect to $\mathrm{K}, \mathrm{Ca}, \mathrm{Mn}, \mathrm{Fe}, \mathrm{Cu}, \mathrm{Zn}, \mathrm{Br}, \mathrm{Rb}$, and $\mathrm{Sr}$ abundances in wine and in 8 out of 10 if only $\mathrm{Fe}, \mathrm{Zn}, \mathrm{Br}, \mathrm{Rb}$, and $\mathrm{Sr}$ were considered (results are shown in Supporting Information, Table S6.3, S6.4). In both cases, a 100\% match was occasionally found between different wine varieties. We believe that this problem can be solved by using $c_{\mathrm{i}}$ (wine)/ $c_{\mathrm{i}}$ (soil) concentration factors instead of wine concentrations. This was proven in Figure 5, showing that discrimination based on $c_{\mathrm{i}}$ (wine) $/ c_{\mathrm{i}}$ (soil) concentration factors of $\mathrm{Fe}, \mathrm{Zn}, \mathrm{Br}, \mathrm{Rb}$, and $\mathrm{Sr}$, in which concentrations were analyzed by XRF techniques, is a very useful method for the authentication of the geographic origin of wines. However, it should be notified that the introduction of new agricultural practices in vineyards, like irrigation (which was not the case for the visited vineyards within this study), can alter the elemental composition of grapes and consequently of finished wines. This, as well as the extreme changes in the weather regime, has to be considered when comparing consecutive production years of the same vintner. ${ }^{33}$

\section{CONCLUSIONS}

We have presented two XRF techniques, EDXRF and TXRF, for the determination of element abundances in wine. The main advantage of XRF over conventional techniques is a nondestructive multi-element analysis of wine samples and preservation of volatiles. We have evaluated concentrations of $\mathrm{Fe}, \mathrm{Cu}, \mathrm{Zn}, \mathrm{Br}, \mathrm{Rb}$, and $\mathrm{Sr}$ in wine and their $c_{\mathrm{i}}$ (wine) $/ c_{\mathrm{i}}$ (soil) concentration factors to distinguish Austrian from Croatian wines. These elements have been determined as the best discriminators for the geographical authentication of wine. The samples were successfully classified showing that XRF techniques are a powerful tool for building large data sets of wine and soil elemental abundances. Such data sets are necessary to evaluate the reflection of soil characteristics on wine composition and are especially useful if $c_{\mathrm{i}}$ (wine) $/ c_{\mathrm{i}}$ (soil) concentration factors are taken into consideration for fingerprinting wine geographic origin.

\section{MATERIALS AND METHODS}

4.1. Collection of Samples. Two bottles of finished wine and corresponding soil were collected during 2017-2018 in cooperation with wine producers from Austria and Croatia. Eleven small-size producers were selected, and 37 samples of different bottled wines were collected (14 samples of red wine Blaufränkisch, 13 samples of white wine Riesling and Welschriesling, three samples of red wine Cabernet Sauvignon, three samples of white wine Žlahtina, two samples of red wine Zweigelt, one sample of white wine Malvasier, and one sample of red wine Debejan). One of the two bottles was transported to the Atominstitut (ATI), Vienna, Austria and analyzed by TXRF. Another bottle of the same wine and corresponding soil were transported to the Ruder Bošković Institute (RBI) and analyzed by EDXRF. Grapes of seven vine varieties were collected during harvesting in the vineyards of the Katunar Estate Winery, Croatia. The sample log of collected wines, grapes, and soils is given in Supporting Information, Tables S1 and $\mathrm{S} 2$.

4.2. Lyophilization. Lyophilization of wine samples intended for EDXRF analysis was performed at the RBI. Two samples of $50 \mathrm{~mL}$ from the wine bottle were poured into plastic containers (size of $58 \times 58 \times 40 \mathrm{~mm}$ ). $10 \mu \mathrm{g}$ of $\mathrm{Se}$ standard reference material (TraceCERT, Fluka Analytical, Switzerland, $1000 \mathrm{mg} / \mathrm{L}$ ) was added into each container as the internal standard since its K-alpha line $(11.18 \mathrm{keV})$ does not overlap with any of the lines of the elements of interest in XRF spectrometry. In addition, the absorption edge of $\mathrm{Se}$ is relatively close to the Mo K-alpha used as the excitation line in TXRF and EDXRF measurements, leading to good excitation efficiency. Containers were frozen in liquid nitrogen and lyophilized for about $40 \mathrm{~h}$ using the Labconco-FreeZone 2.5 L lyophilizer (USA) at $-80^{\circ} \mathrm{C}$ and pressure of 0.015 mbars to remove water and alcohol from the sample. It is recommended that the height of the frozen sample does not exceed $1.5-2 \mathrm{~cm}$ for optimal lyophilization. Approximately $1 \mathrm{~g}$ of viscous sample was obtained; thus, the wine samples were pre-concentrated by 


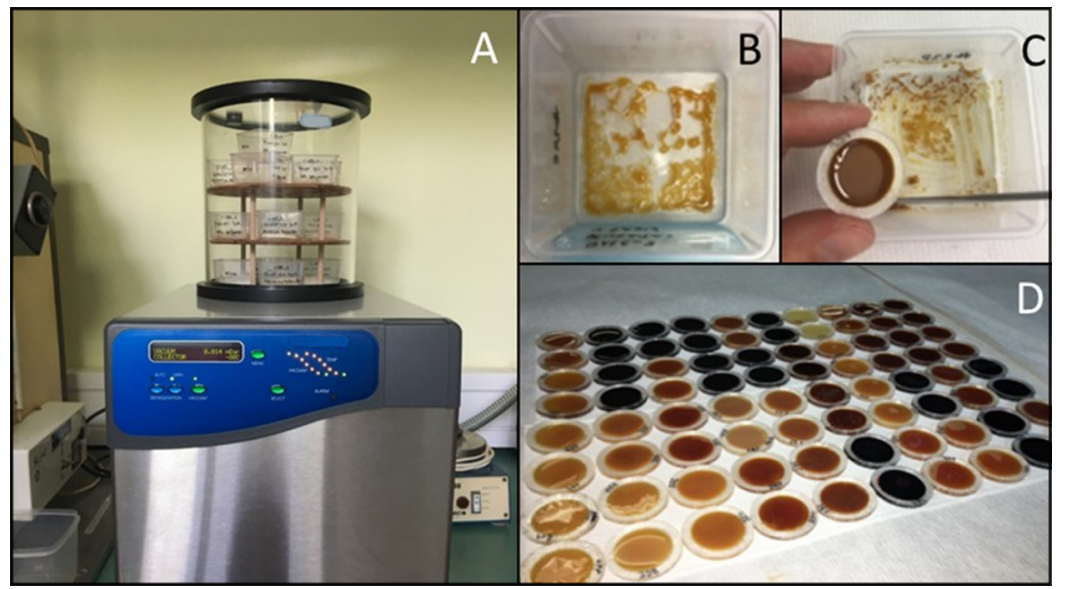

Figure 6. Preparation of wine samples for EDXRF analysis. (A) Labconco-FreeZone 2.5 L lyophilizer; (B) sample of wine after completed lyophilization; (C) round plastic holder with approximately $1 \mathrm{~g}$ of the viscous wine sample; and (D) wine samples prepared for analysis. Photograph courtesy of Canadija I. Copyright 2021.

approximately a factor of 50 . Grape juice was prepared in the laboratory. Grapes were washed in distilled water and squeezed, and non-filtered juice was lyophilized in the same way as wines. Skins and seeds were removed.

4.3. EDXRF Analysis of Wine and Grape Juice. The lyophilized sample was transferred into a plastic holder with the bottom of mylar foil ( $3 \mu \mathrm{m}$ thick). Another layer of mylar foil was carefully glued to the top of the holder to prevent outpouring and contamination of the samples. Figure 6 shows the preparation of wine samples after lyophilization.

Wine samples were analyzed using a RBI EDXRF spectrometer build in house and equipped with the $\mathrm{W}$ anode Philips X-ray tube (Netherlands) and Mo secondary target. Working parameters of the tube were set to $35 \mathrm{kV}$ and $35 \mathrm{~mA}$, and the irradiation time was $1000 \mathrm{~s}$. Samples were irradiated in air to prevent degassing of volatile components. X-ray spectra were collected using a liquid nitrogen-cooled Canberra $\mathrm{Si}(\mathrm{Li})$ detector (USA) with the active surface of $30 \mathrm{~mm}^{2}$, the thickness of $3 \mathrm{~mm}$, Be window thickness of $0.025 \mathrm{~mm}$, and FWHM of $170 \mathrm{eV}$ at $5.9 \mathrm{keV}$. Spectra were analyzed using IAEA QXAS software. TraceCERT, Fluka Analytical (Switzerland) $1000 \mathrm{mg} / \mathrm{L}$ certified reference materials were used to create calibration lines for elements in the wine. Calibration lines were used to calculate a sensitivity plot (Supporting Information, Figure S1) which was used for the quantification of elements $\mathrm{K}, \mathrm{Ca}, \mathrm{Mn}, \mathrm{Fe}, \mathrm{Cu}, \mathrm{Zn}, \mathrm{Br}, \mathrm{Rb}$, and Sr. Figure 7 shows a typical spectrum obtained using the EDXRF technique. Relative uncertainties of results calculated as the errors of the correlation lines' coefficients were $\mathrm{K}-15.22 \%$, $\mathrm{Ca}-16.66 \%, \mathrm{Mn}-10.03 \%, \mathrm{Fe}-5.32 \%, \mathrm{Ni}-12.57, \mathrm{Cu}-$ $1.67 \%, \mathrm{Zn}-8.12 \%, \mathrm{Br}-9.36 \%, \mathrm{Rb}-5.34 \%$, and $\mathrm{Sr}-1.98 \%$. Minimum detection limits (MDLs) were found from the random wine sample using the equation $\mathrm{MDL}=c \times 3 \sqrt{ } N_{\mathrm{c}} / B$, where $c$ is the known concentration of the element of interest, $N_{\mathrm{c}}$ is the number of counts under the characteristic X-ray peak, and $B$ is the number of counts from the background. The uncertainty of results was influenced by the matrix effects and the proximity of peaks of elements found in high concentrations. MDLs in wines were $96 \mathrm{mg} / \mathrm{L}$ for $\mathrm{K}, 331$ $\mathrm{mg} / \mathrm{L}$ for Ca, $11 \mu \mathrm{g} / \mathrm{L}$ for $\mathrm{Mn}, 7 \mu \mathrm{g} / \mathrm{L}$ for $\mathrm{Fe}, 6 \mu \mathrm{g} / \mathrm{L}$ for $\mathrm{Cu}$, $1.3 \mu \mathrm{g} / \mathrm{L}$ for $\mathrm{Zn}, 0.8 \mu \mathrm{g} / \mathrm{L}$ for $\mathrm{Br}$, and $0.5 \mu \mathrm{g} / \mathrm{L}$ for $\mathrm{Rb}$ and $\mathrm{Sr}$. Final concentrations in wine were obtained as the average of two duplicate measurements.

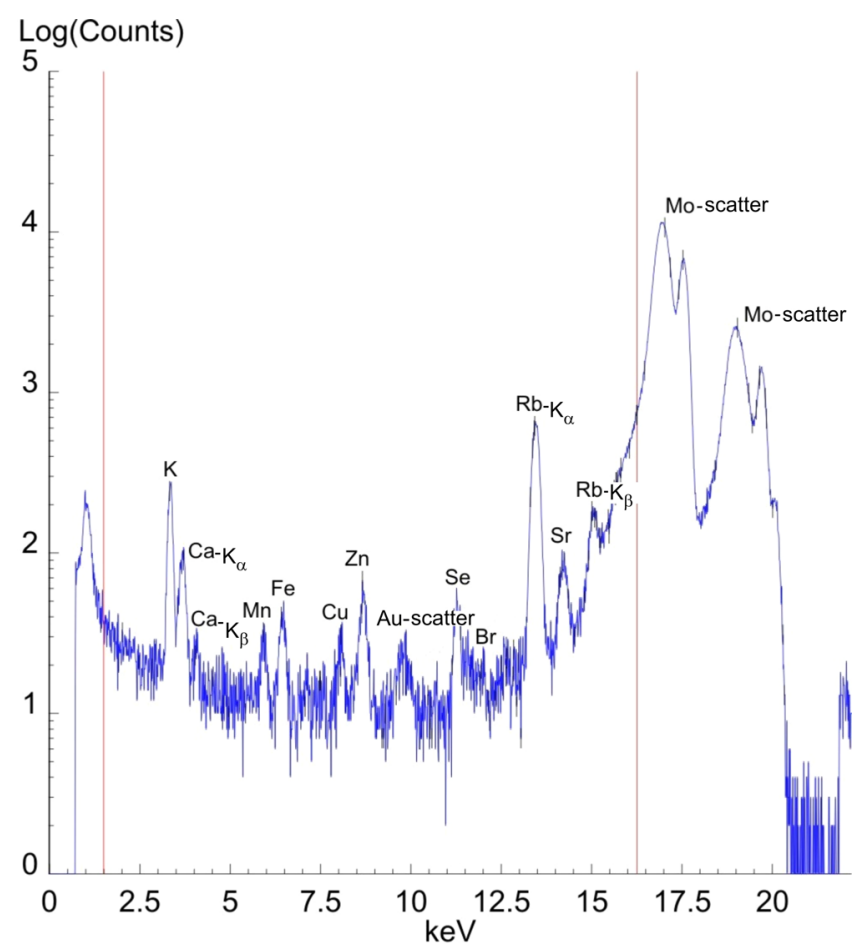

Figure 7. Typical EDXRF spectrum of wine.

4.4. EDXRF Analysis of Soil. Two soil samples were collected from vineyards of respective wines. Around $1 \mathrm{~kg}$ of each sample was taken from a depth of about $20 \mathrm{~cm}$. Samples were dried in an oven at $100{ }^{\circ} \mathrm{C}$ to constant weight. Afterward, they were sieved $(\Phi=2 \mathrm{~mm})$, homogenized, ground using mortar and pestle, and sieved again $(\Phi=45 \mu \mathrm{m})$. Samples were then pressed into pellets weighing around $2 \mathrm{~g}$ with a diameter of $2.5 \mathrm{~cm}$. Soil samples were irradiated in a vacuum to increase the sensitivity for light elements. Concentrations of elements $\mathrm{K}, \mathrm{Ca}, \mathrm{Ti}, \mathrm{V}, \mathrm{Cr}, \mathrm{Mn}, \mathrm{Fe}, \mathrm{Ni}, \mathrm{Cu}, \mathrm{Zn}, \mathrm{Ga}, \mathrm{As}, \mathrm{Br}, \mathrm{Rb}$, $\mathrm{Sr}, \mathrm{Y}, \mathrm{Zr}, \mathrm{Pb}$, and $\mathrm{Th}$ were determined by direct comparison with the IAEA reference material Soil-7. The instrumentation and measurement parameters were the same as for the wine analysis described above. Uncertainty of results and MDLs were calculated from the standard reference material Soil-7. The relative uncertainties of results were $\mathrm{K}-5.8 \%, \mathrm{Ca}-5.2 \%$, 


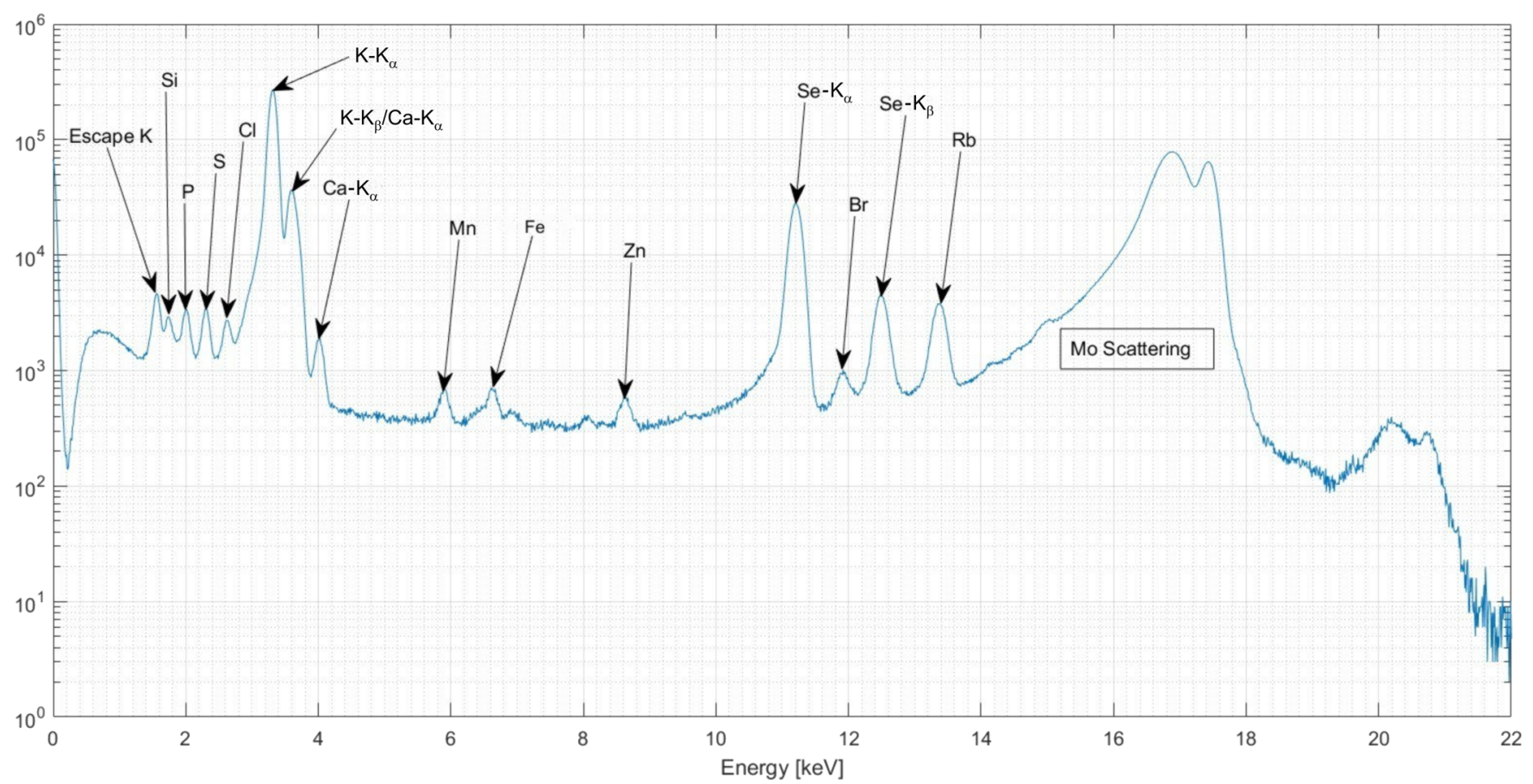

Figure 8. Typical TXRF spectrum of wine.

$\mathrm{Ti}-18.3 \%, \mathrm{~V}-10.6 \%, \mathrm{Cr}-20.8 \%, \mathrm{Mn}-3.7 \%, \mathrm{Fe}-2.1 \%$, $\mathrm{Ni}-30.7 \%, \mathrm{Cu}-22 \%, \mathrm{Zn}-5.75 \%, \mathrm{Ga}-10.0 \%$, As-6.3\%, $\mathrm{Br}-42.9 \%, \mathrm{Rb}-8.8 \%, \mathrm{Sr}-5.1 \%, \mathrm{Y}-28.6 \%, \mathrm{Zr}-5.7 \%$, and $\mathrm{Pb}-26.6 \%$. MDLs in soils (calculated by the same equation used for wines described above) were $1 \mathrm{mg} / \mathrm{kg}$ for As and $\mathrm{Pb}$, $1.5 \mathrm{mg} / \mathrm{kg}$ for $\mathrm{Sr}, 2 \mathrm{mg} / \mathrm{kg}$ for $\mathrm{Cu}, \mathrm{Rb}$, and $\mathrm{Y}, 3 \mathrm{mg} / \mathrm{kg}$ for $\mathrm{Zn}$ and $\mathrm{Br}, 5 \mathrm{mg} / \mathrm{kg}$ for $\mathrm{Ga}, \mathrm{Zr}$, and $\mathrm{Th}, 13 \mathrm{mg} / \mathrm{kg}$ for $\mathrm{Cr}, \mathrm{Ni}$, and $\mathrm{Fe}, 20 \mathrm{mg} / \mathrm{kg}$ for $\mathrm{Mn}$ and $\mathrm{V}, 100 \mathrm{mg} / \mathrm{kg}$ for Ti, $270 \mathrm{mg} / \mathrm{kg}$ for $\mathrm{Ca}$, and $660 \mathrm{mg} / \mathrm{kg}$ for $\mathrm{K}$.

4.5. TXRF Analysis of Wine. Quartz reflectors with a diameter of $30 \mathrm{~mm}$ were used as the sample holders. They were manually cleaned following a routine procedure which includes washing the reflectors with re-distilled water and acetone and boiling them in a specific washing solution and in nitric acid. The wine analysis was started by adding $50 \mu \mathrm{L}$ of a $1000 \mathrm{mg} / \mathrm{L}$ Se TraceCERT, Fluka Analytical (Switzerland) standard solution to $4.95 \mathrm{~mL}$ of the respective wine sample. Each wine sample containing the internal standard was analyzed in triplets by adding $10 \mu \mathrm{L}$ on a quartz reflector, on which a silicon solution was previously applied to guarantee the optimal wetting of the reflector. The samples were then dried on a hot plate to eliminate the water and alcohol from the wine solution. Wine samples were analyzed by the TXRF spectrometer Atomika 8030C (ATI). The spectrometer is equipped with a water-cooled $2.5 \mathrm{~kW}$ X-ray tube with a Mo$\mathrm{W}$ anode. The K-alpha line of molybdenum filtered from the primary beam using a multilayer monochromator was used for the analysis of the probes. The spectrometer has a liquid nitrogen cooled $\mathrm{Si}(\mathrm{Li})$ detector. The measurement parameters were $50 \mathrm{kV} / 47 \mathrm{~mA}$, and measurement time was $1000 \mathrm{~s}$. The obtained spectra were fitted with Atomika software. The minimum criteria for the presence of an element were the concentrations measured above three standard deviations. In all spectra, an escape peak of potassium K-alpha at $1.57 \mathrm{keV}$ was observed. The relative uncertainties of results were $20 \%$ for $\mathrm{K}, \mathrm{Cu}, \mathrm{Zn}, \mathrm{Br}$, and $\mathrm{Rb}, 25 \%$ for $\mathrm{Sr}$, and $30 \%$ for $\mathrm{Ca}, \mathrm{Mn}$, and Fe. MDLs were $\mathrm{K}-60 \mu \mathrm{g} / \mathrm{L}, \mathrm{Ca}-200 \mu \mathrm{g} / \mathrm{L}, \mathrm{Mn}$ and
$\mathrm{Fe}-10 \mu \mathrm{g} / \mathrm{L}, \mathrm{Cu}-5 \mu \mathrm{g} / \mathrm{L}, \mathrm{Zn}, \mathrm{Br}$, and $\mathrm{Rb}-4 \mu \mathrm{g} / \mathrm{L}$, and $\mathrm{Sr}-$ $3 \mu \mathrm{g} / \mathrm{L}$. Figure 8 presents a typical TXRF spectrum of the wine sample.

4.6. ICP-MS Analysis of Wine. Multielement analysis was performed by high-resolution HR-ICP-MS using an Element 2 instrument (Thermo, Germany) on eight wine samples. Typical instrument conditions and measurement parameters used throughout the work were reported earlier. ${ }^{34,35}$ Standards for trace element analysis were prepared by appropriate dilution of a multielement reference standard $(100 \pm 0.2 \mathrm{mg} /$ $\mathrm{L}$, Analytika, Czech Republic) containing $\mathrm{Mn}, \mathrm{Fe}, \mathrm{Cu}, \mathrm{Zn}$, and $\mathrm{Sr}$ in which single-element standard solutions of $\mathrm{Rb}(1.000 \pm$ $0.002 \mathrm{~g} / \mathrm{L}$, Aldrich, USA) was added. All standards and blanks were prepared by addition of $2 \%$ high purity $\mathrm{HNO}_{3}$ (Fluka, Switzerland) and 1\% EtOH (p.a. quality, Kemika, Croatia), and $\mathrm{In}(1 \mu \mathrm{g} / \mathrm{L})$ was added as the internal standard.

Prior to analysis of $\mathrm{Mn}, \mathrm{Cu}, \mathrm{Zn}, \mathrm{Rb}$ and $\mathrm{Sr}$, wine samples were 10 -fold diluted. In the case of Fe analysis, samples were 100 -fold diluted. Wine samples were acidified with $2 \%(\mathrm{v} / \mathrm{v})$ $\mathrm{HNO}_{3}(65 \%$, supra pur, Fluka, Switzerland), and In $(1 \mu \mathrm{g} / \mathrm{L})$ was added as the internal standard. All wine samples were analyzed for total concentrations of six elements $(\mathrm{Mn}, \mathrm{Fe}, \mathrm{Cu}$, $\mathrm{Zn}, \mathrm{Rb}$, and $\mathrm{Sr}$ ). The relative uncertainties of results calculated as a relative standard deviation $=\mathrm{STDEV} / \mathrm{AVG} \times 100$ were $\mathrm{Mn}-5 \%, \mathrm{Fe}-6 \%, \mathrm{Cu}-6 \%, \mathrm{Zn}-5 \%, \mathrm{Rb}-3 \%$, and $\mathrm{Sr} 3 \%$. The MDLs calculated as three times the standard deviation of 10 consecutive measurements of the analyte concentration in the procedural blank were $\mathrm{Mn}-0.01 \mu \mathrm{g} / \mathrm{L}, \mathrm{Fe}-0.2 \mu \mathrm{g} / \mathrm{L}$, $\mathrm{Cu}-0.04 \mu \mathrm{g} / \mathrm{L}, \mathrm{Zn}-0.15 \mu \mathrm{g} / \mathrm{L}, \mathrm{Rb}-0.03 \mu \mathrm{g} / \mathrm{L}$, and $\mathrm{Sr}-$ $0.02 \mu \mathrm{g} / \mathrm{L}$.

4.7. Statistical Analysis. Descriptive statistic for concentrations of elements in wine obtained using EDXRF, TXRF, and ICP-MS and in grape juice and soil obtained using EDXRF was calculated with Statistica 6 software. The distribution of results obtained using EDXRF, TXRF, and ICP-MS for elements $\mathrm{Mn}, \mathrm{Fe}, \mathrm{Cu}, \mathrm{Zn}, \mathrm{Rb}$, and $\mathrm{Sr}$ was evaluated by the KW test at the significance level of $p<0.05$ to 
find whether the measured concentrations belong to the same distribution (distributions do not differ if the test is nonsignificant). SigmaPlot 11 was used for linear regression analysis of the results obtained using EDXRF and TXRF. BGPCA was performed using open-source software Ade $4^{36}$ on normalized data and predetermined classes of wines, according to the country of origin (1-Austria and 2-Croatia). The concentrations of elements $\mathrm{Fe}, \mathrm{Zn}, \mathrm{Br}, \mathrm{Rb}$, and $\mathrm{Sr}$ measured in wine and $c_{\mathrm{i}}($ wine $) / c_{\mathrm{i}}$ (soil) concentration factors of the same elements were evaluated. Pearson's R correlations between concentrations of elements in wine and soils were evaluated for 32 valid samples at the significant level of $p<0.05$. Spearman Rank Order correlations for concentrations of elements in common (nine variables- $\mathrm{K}, \mathrm{Ca}, \mathrm{Mn}, \mathrm{Fe}, \mathrm{Cu}, \mathrm{Zn}, \mathrm{Br}, \mathrm{Rb}$, and $\mathrm{Sr}$ concentrations) were determined between two wines, and respective grape juice and soils at the significance level of $p<$ 0.05 .

\section{ASSOCIATED CONTENT}

\section{s) Supporting Information}

The Supporting Information is available free of charge at https://pubs.acs.org/doi/10.1021/acsomega.1c02731.

Sample log of collected wines, grapes, and soils; EDXRF sensitivity plot; results of chemical and statistical analyses; additional references and frequency of elements appearing in papers as discriminators for wine fingerprinting; results of correlation analysis; and $c_{\mathrm{i}}$ (wine) $/ c_{\mathrm{i}}$ (soil) concentration ratios of $\mathrm{Fe}, \mathrm{Zn}, \mathrm{Br}, \mathrm{Rb}$, and $\mathrm{Sr}$ (XLSX)

\section{AUTHOR INFORMATION}

\section{Corresponding Author}

Jasmina Obhodaš - Ruder Boškovic Institute, Zagreb 10000, Croatia; ○ orcid.org/0000-0002-9347-922X;

Email: jobhodas@irb.hr

\section{Authors}

Vladivoj Valković - Ruder Bǒ̌ković Institute, Zagreb 10000, Croatia

Andrija Vinković - Ruder Boškovíc Institute, Zagreb 10000, Croatia

Davorin Sudac - Ruder Boškovic Institute, Zagreb 10000, Croatia

Ivana Canadija - University of Zagreb, Zagreb 10000, Croatia

Tihana Pensa - University of Zagreb, Zagreb 10000, Croatia; Present Address: Ph.D. Student, Ali I. Al-Naimi Petroleum Engineering Research Center (ANPERC), King Abdullah University of Science and Technology (KAUST), Building 5, Level 0, Office 0872, Thuwal, 23955-6900, Kingdom of Saudi Arabia. Phone: +966 (56) 867274

Željka Fiket - Ruder Boškovic Institute, Zagreb 10000, Croatia

Anna Turyanskaya - TU Wien, Atominstitut, Wien 1020, Austria

Thomas Bretschneider - TU Wien, Atominstitut, Wien 1020, Austria

Christoph Wilhelmer - TU Wien, Atominstitut, Wien 1020, Austria

Gerelmaa Gunchin - TU Wien, Atominstitut, Wien 1020, Austria
Peter Kregsamer - TU Wien, Atominstitut, Wien 1020, Austria

Peter Wobrauschek - TU Wien, Atominstitut, Wien 1020, Austria

Christina Streli - TU Wien, Atominstitut, Wien 1020, Austria; O orcid.org/0000-0002-5141-3177

Complete contact information is available at:

https://pubs.acs.org/10.1021/acsomega.1c02731

\section{Notes}

The authors declare no competing financial interest.

\section{ACKNOWLEDGMENTS}

Our special thanks are extended to Austrian and Croatian winemakers for donating their wines, for their time and assistance during vineyards sampling, and for fruitful discussions that have contributed to this study. The research was partially funded by NGO "Lijepa naša," Zagreb, Croatia, partially by "Scientific \& Technological Cooperation between Austria and Croatia" 2018/19 grant, project no. HR 23/2018 (WTZ Kroatien-HR 23/2018), and partially by European Cooperation in Science and Technology, grant/award number: ENFORCE TXRF/CA18130. A.V. acknowledges HRZZ DOK-01-2018 grant.

\section{REFERENCES}

(1) Fabani, M. P.; Arrúa, R. C.; Vázquez, F.; Diaz, M. P.; Baroni, M. V.; Wunderlin, D. A. Evaluation of elemental profile coupled to chemometrics to assess the geographical origin of Argentinean wines. Food Chem. 2010, 119, 372-379.

(2) Schiavo, D.; Neira, J. Y.; Nóbrega, J. A. Direct determination of $\mathrm{Cd}, \mathrm{Cu}$ and $\mathrm{Pb}$ in wines and grape juices by thermospray flame furnace atomic absorption spectrometry. Talanta 2008, 76, 11131118.

(3) Almeida, C. M. R.; Vasconcelos, M. T. S. D.; Barbaste, M.; Medina, B. ICP-MS multi-element analysis of wine samples - a comparative study of the methodologies used in two laboratories. Anal. Bioanal. Chem. 2002, 374, 314-322.

(4) Grindlay, G.; Mora, J.; Gras, L.; De Loos-Vollebregt, M. T. C. Ultratrace determination of $\mathrm{Pb}, \mathrm{Se}$ and $\mathrm{As}$ in wine samples by electrothermal vaporization inductively coupled plasma mass spectrometry. Anal. Chim. Acta 2009, 652, 154-160.

(5) Kruzlicova, D.; Fiket, Ž.; Kniewald, G. Classification of Croatian wine varieties using multivariate analysis of data obtained by high resolution ICP-MS analysis. Food Res. Int. 2013, 54, 621-626.

(6) Horii, S.; Hashiguchi, T.; Izu, H.; Sudo, S. Analysis of Element Composition of Japanese and Other Wine and Their Classification. J. Jpn. Soc. Hortic. Sci. 2011, 80, 506-511.

(7) Sen, I.; Tokatli, F. Characterization and Classification of Turkish Wines Based on Elemental Composition. Am. J. Enol. Vitic. 2013, 65, 134-142.

(8) Dalipi, R.; Borgese, L.; Zacco, A.; Tsuji, K.; Sangiorgi, E.; Piro, R.; Bontempi, E.; Depero, L. E. Determination of trace elements in Italian wines by means of total reflection X-ray fluorescence spectroscopy. Int. J. Environ. Anal. Chem. 2015, 95, 1208-1218.

(9) Dalipi, R.; Marguí, E.; Borgese, L.; Bilo, F.; Depero, L. E. Analytical performance of benchtop total reflection X-ray fluorescence instrumentation for multielemental analysis of wine samples. Spectrochim. Acta, Part B 2016, 120, 37-43.

(10) Gruber, X.; Kregsamer, P.; Wobrauschek, P.; Streli, C. Totalreflection X-ray fluorescence analysis of Austrian wine. Spectrochim. Acta, Part B 2006, 61, 1214-1218.

(11) Sudac, D.; Obhodaš, J.; Obhodaš, J.; Vinković, A.; Kutle, A.; Valković, V. Authentication of Geographic Origin of Wine by using EDXRF and Multivariate Statistics. J. Basic Appl. Sci. 2019, 15, 40-47. 
(12) Orescanin, V.; Katunar, A.; Kutle, A.; Valkovic, V. Heavy Metals in Soil, Grape, and Wine. J. Trace Microprobe Tech. 2003, 21, 171-180.

(13) Anjos, M. J.; Barroso, R. C.; Lopes, R. T.; De Jesus, E. F. O.; Simabuco, S. M.; Castro, C. R. F. EDXRF analysis of red and white wines from Brazil. X-Ray Spectrom. 2004, 33, 407-409.

(14) Galgano, F.; Favati, F.; Caruso, M.; Scarpa, T.; Palma, A. Analysis of trace elements in southern Italian wines and their classification according to provenance. LWT-Food Sci. Technol. 2008, 41, 1808-1815.

(15) Boschetti, W.; Rampazzo, R. T.; Dessuy, M. B.; Vale, M. G. R.; De Oliveira Rios, A.; Hertz, P.; Manfroi, V.; Celso, P. G.; Ferrão, M. F. Detection of the origin of Brazilian wines based on the determination of only four elements using high-resolution continuum source flame AAS. Talanta 2013, 111, 147-155.

(16) Dinca, O. R.; Ionete, R. E.; Costinel, D.; Geana, I. E.; Popescu, R.; Stefanescu, I.; Radu, G. L. Regional and Vintage Discrimination of Romanian Wines Based on Elemental and Isotopic Fingerprinting. Food Anal. Methods 2016, 9, 2406-2417.

(17) Martin, A. E.; Watling, R. J.; Lee, G. S. The multi-element determination and regional discrimination of Australian wines. Food Chem. 2012, 133, 1081-1089.

(18) Orellana, S.; Johansen, A. M.; Gazis, C. Geographic classification of U.S. Washington State wines using elemental and water isotope composition. Food Chem.: X 2019, 1, 100007.

(19) Pérez-Álvarez, E. P.; Garcia, R.; Barrulas, P.; Dias, C.; Cabrita, M. J.; Garde-Cerdán, T. Classification of wines according to several factors by ICP-MS multi-element analysis. Food Chem. 2019, 270, $273-280$.

(20) Šelih, V. S.; Šala, M.; Drgan, V. Multi-element analysis of wines by ICP-MS and ICP-OES and their classification according to geographical origin in Slovenia. Food Chem. 2014, 153, 414-423.

(21) Tanabe, C. K.; Nelson, J.; Boulton, R. B.; Ebeler, S. E.; Hopfer, H. The Use of Macro, Micro, and Trace Elemental Profiles to Differentiate Commercial Single Vineyard Pinot noir Wines at a SubRegional Level. Molecules 2020, 25, 2552.

(22) Almeida, C. M. R.; Vasconcelos, M. T. S. D. Multielement Composition of Wines and Their Precursors Including Provenance Soil and Their Potentialities as Fingerprints of Wine Origin. J. Agric. Food Chem. 2003, 51, 4788-4798.

(23) Di Paola-Naranjo, R. D.; Baroni, M. V.; Podio, N. S.; Rubinstein, H. R.; Fabani, M. P.; Badini, R. G.; Inga, M.; Ostera, H. A.; Cagnoni, M.; Gallegos, E.; Gautier, E.; Peral-García, P.; Hoogewerff, J.; Wunderlin, D. A. Fingerprints for Main Varieties of Argentinean Wines: Terroir Differentiation by Inorganic, Organic, and Stable Isotopic Analyses Coupled to Chemometrics. J. Agric. Food Chem. 2011, 59, 7854-7865.

(24) Taylor, V. F.; Longerich, H. P.; Greenough, J. D. Multielement Analysis of Canadian Wines by Inductively Coupled Plasma Mass Spectrometry (ICP-MS) and Multivariate Statistics. J. Agric. Food Chem. 2003, 51, 856-860.

(25) van der Linde, G.; Fischer, J. L.; Coetzee, P. P. Multi-element Analysis of South African Wines and their Provenance Soils by ICPMS and their Classification according to Geographical Origin using Multivariate Statistics. S. Afr. J. Enol. Vitic. 2010, 31, 143-153.

(26) Zinicovscaia, I.; Duliu, O. G.; Culicov, O. A.; Sturza, R.; Bilici, C.; Gundorina, S. Geographical Origin Identification of Moldavian Wines by Neutron Activation Analysis. Food Anal. Methods 2017, 10, 3523-3530.

(27) Blotevogel, S.; Schreck, E.; Laplanche, C.; Besson, P.; Saurin, N.; Audry, S.; Viers, J.; Oliva, P. Soil chemistry and meteorological conditions influence the elemental profiles of West European wines. Food Chem. 2019, 298, 125033.

(28) OIV. International Code of Oenological Practices, OIV Code Sheet - Issue 2021/01. 2021, http://www.oiv.int/public/medias/ 3741/e-code-annex-maximum-acceptable-limits.pdf (accessed Apr 16, 2021).
(29) EC. Commission Regulation (EC) 2019/934. 2020, https:// eur-lex.europa.eu/legal-content/EN/TXT/PDF/?uri= CELEX:02019R0934-20190627\&from=EN (accessed Apr 16, 2021).

(30) Popescu-Mitroi, I.; Radu, D. Potassium ferrocyanide wine treatment: a controversial, yet necessary operation. Sci. Tech. Bull., Ser. Chem. Food Sci. Eng. 2017, 14, 4-8.

(31) Reschke, S.; Tran, T.; Bekker, M.; Wilkes, E.; Johnson, D. Using copper more effectively in winemaking. Wine Vitic. J. 2015, 30, 35-39.

(32) Friedenberg, D. S.; Manns, D. C.; Perry, D. M.; Mansfield, A. K. Removal of Copper from White Wine: Imidazole-Based Polymers are Efficient at Copper Adsorption. Catal. Discovery Pract. 2018, 2, 1-6.

(33) Sofo, A.; Nuzzo, V.; Tataranni, G.; Manfra, M.; De Nisco, M.; Scopa, A. Berry morphology and composition in irrigated and nonirrigated grapevine (Vitis vinifera L.). J. Plant Physiol. 2012, 169, $1023-1031$

(34) Fiket, Ž.; Mikac, N.; Kniewald, G. Arsenic and other trace elements in wines of eastern Croatia. Food Chem. 2011, 126, 941947.

(35) Fiket, Ž.; Mikac, N.; Kniewald, G. Mass fractions of forty-six major and trace elements, including rare earth elements, in sediment and soil reference materials used in environmental studies. Geostand. Geoanal. Res. 2016, 41, 123-135.

(36) Thioulouse, J.; Chessel, D.; Dolédec, S.; Olivier, J.-M. ADE-4: a multivariate analysis and graphical display software. Stat. Comput. 1997, 7, 75-83. 